\title{
ONEHUNDRED YEARSOFRITA
}

From a home lab to the Italian Senate, by way of nerve growth factor - Rita Levi-Montalcini is a scientist like no other. Alison Abbott meets the first Nobel prizewinner set to reach her hundredth birthday. 


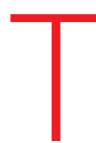

iny though she is, Rita Levi-Montalcini tends to command attention. And on the morning of 18 November 2006, she had the attention of the entire Italian government. A senator for life, Levi-Montalcini held the deciding vote on a budget backed by the government of Romano Prodi, which held a parliamentary majority of just one.

A few days earlier, Levi-Montalcini had said she would withdraw her support for the budget unless the government reversed a last-minute decision to sacrifice science funds. It was LeviMontalcini versus Prodi - and Levi-Montalcini won. On the morning of the vote, immaculately turned out as always, she walked regally on the arm of an usher to her seat in the Italian senate and cast her vote. At one stroke, she secured the budget, won a battle for Italian science and snubbed Francesco Storace, leader of the Right party and part of the opposition coalition. A few weeks earlier, Storace had caused a national scandal by announcing his intention to send crutches to Levi-Montalcini's home - symbolic of her both being a crutch to an ailing government, he said, and her age, which he considered too old to be allowed to vote.

Levi-Montalcini didn't consider herself too old then, when she was 97 years old, and she certainly doesn't now when, on 22 April, she will become the first Nobel laureate to reach the age of 100. Italy - and quite possibly the world - has never seen a scientist quite like her.

Born into a well-to-do Jewish family in Turin in 1909, Levi-Montalcini fought hard for her career from the beginning. First there was her domineering father, who didn't believe in higher education for women. Then there were Benito Mussolini's race laws, which ejected Jews from universities and forced her into hiding. And after that there was the scientific establishment, which refused to believe in the existence of nerve growth factor (NGF), the discovery of which eventually won LeviMontalcini a share of the 1986 Nobel Prize in Physiology or Medicine, together with her colleague Stanley Cohen. "That discovery was huge - it opened up a whole field in understanding how cells talk and listen to each other," says neuroscientist Bill Mobley of Stanford University in California, an admirer for more than 30 years. Hundreds of growth factors are now known to exist and they affect almost all facets of biology.

Despite her age, Levi-Montalcini still works every day, exquisitely dressed, hair stylishly coiffured, hands perfectly manicured. In the mornings she shows up at her namesake European Brain Research Institute (EBRI)Rita Levi-Montalcini, on the outskirts of Rome. In the afternoons she goes downtown to the offices of an educational foundation for
African women that she created in 1992.

Turning 100 is no reason to stop fighting. "It's not enough what I did in the past - there is also the future," Levi-Montalcini says. She has never hesitated to use her Senate position to push for better scientific prospects in the country. And today she has something even closer to her heart to fight for - the survival of the EBRI, which she created in 2002 and which is now in financial straits.

Levi-Montalcini spent a large part of her research career in the United States. But her early, and late, scientific life has been based in Italy. Three years after leaving high school, she finally persuaded her father to allow her to study medicine, and in 1930 she enrolled at the University of Turin. Her first mentor was Giuseppe Levi, a prominent neurohistologist. In her autobiography In Praise of Imperfection, Levi-Montalcini refers to him as "the Master" - he was an outspoken antifascist, renowned for his alarming fits of rage. But he was also the man who introduced her to her first passion: the developing nervous system. Under Levi's attentive eye, she mastered a technique that would be key to her own successes, that of silver-staining nerve cells. Developed by Camillo Golgi in the late nineteenth century and later refined by the Spanish neuroscientist Santiago Ramón y Cajal, the technique allowed individual nerves to be seen under the microscope with perfect clarity.

Levi-Montalcini's independent research started when Mussolini's race laws were passed in 1938, and all Jews were expelled from universities and other public institutions (Levi, too, was thrown out). Inspired by the story of Cajal, who had worked alone in a makeshift lab in out-of-the-way Valencia, she set up a bedroom laboratory at her family home. When Levi returned to Turin some time later, he joined her at her bedroom bench.

She had already identified her research challenge: to work out how nerves emerging from the embryo's developing spinal cord find their way to the budding limbs they will eventually innervate. She had recently come across an exciting paper ${ }^{1}$ published a few years earlier by embryologist Viktor Hamburger at Washington University in St Louis, Missouri. Hamburger had removed the growing limbs of chick embryos and found that doing so reduced the size of the ganglia, tiny structures that cluster together the nerve fibres emerging from the spinal cord and direct them on to their final destinations. He put this atrophy down to the absence of what he called an inductive factor released by the tissue to be innervated and, he proposed, necessary to make precursor cells proliferate and then differentiate into neurons.

\section{Detailed dissections}

Hamburger, though, could not see the nerve fibres in great detail using the light microscope. So Levi-Montalcini decided to repeat the experiment with the silver-staining method. Like Cajal, she reasoned she would need little more than an incubator and a microscope - and a regular supply of ferti-

lized hen's eggs. Using tiny scalpels and spatulas fashioned out of sewing needles to do her dissections, she saw that the ganglia did not, in fact, wither immediately. The neurons actually proliferated, differentiated and started to grow towards their targets. It was just that they died before reaching them. She concluded that the problem was not the lack of an inductive factor, but of a growth-promoting one that would normally be released by the budding limbs ${ }^{2}$.

Towards the end of 1942, bombing forced the Levi-Montalcini family to move into the countryside, where she continued her research undaunted, cycling to farms to buy fertilized eggs. She stopped only when Italy switched allegiance to the Allies in 1943, and Hitler's troops invaded northern Italy.

After the war, Levi-Montalcini returned to Turin as Levi's assistant. But at 36, the role no longer suited her - after all, he had been an occasional assistant to her in the days of her bedroom lab. She found her way out when Hamburger, who had read the papers she had published with Levi during the war, invited her to St Louis for a semester to repeat and extend her experiments.

Just as she was doing those experiments, something happened that extended her stay in St Louis from one semester to 26 years. One of Hamburger's graduate students, Elmer Bueker, was trying to see if any piece of fast-growing tissue could attract nerve fibres in the same way that fast-growing developing limbs do. He grafted a lump of proliferating mouse sarcoma 


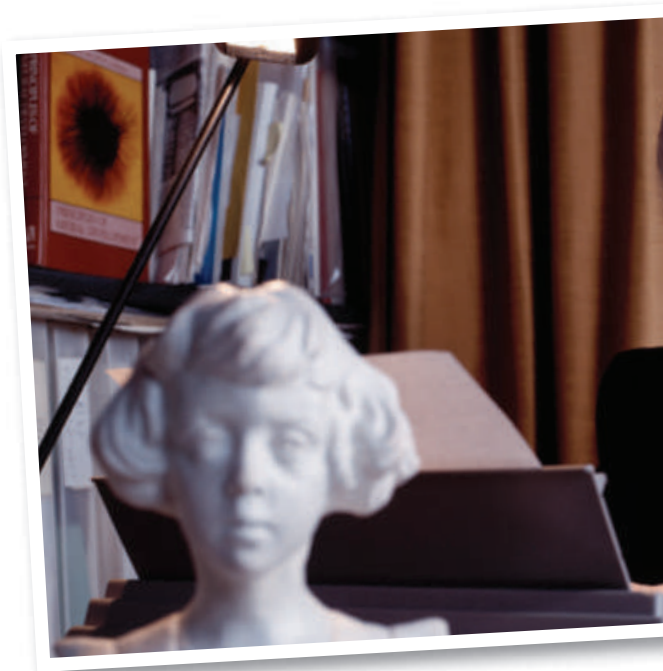

people in the NGF field at one time or another — including myself," recalls Bradshaw. At meetings, she had a tendency to educate audiences on the order in which discoveries had been made, recalls Greene. After one of his own talks, hers was the first hand raised. "It was not a question, but a long statement about NGF and its history," he says. "As she spoke, she little-bylittle made her way to the stage and the podium, and the next thing I knew, she was next to me at the microphone still asking her 'question." Under the circumstances, he says, he could do no more than "step aside, cede the microphone to her, raise my eyebrows and let her finish".

\section{Peacemaker}

In the early 1980s, Levi-Montalcini started to bury the hatchet with everyone in the field, says Bradshaw. Their own quarrel - over a paper he had published without showing her first - was patched up when she took him aside for a chat at a meeting. "It ended what had been a strained and difficult time for me," says Bradshaw. "But Rita had to endure a great deal of scepticism in the early days and there were times when she was justifiably defensive." Her later discoveries faced no such scepticism. She showed, for example, that NGF had major effects on the immune system, yet another unexpected finding that became a major turning point in biology ${ }^{7}$

By the time she and Cohen were awarded the Nobel prize, considerable peace had been achieved. But controversy picked up again in the wake of the award. Some were upset by what they saw as her failure to acknowledge her debt to others, such as Levi and Hamburger. Hamburger, who lived to be 100 , claimed that their friendship suffered after she explained publicly why he should not have shared the prize with her as some had thought appropriate.

But such criticism gained no traction in Italy, where Levi-Montalcini had by now settled permanently. Many viewed her as a national treasure for her achievements, outsize personality, energy and eloquence. Her CNR institute became one of the largest biological research centres in the country. She also took it on
Levi-Montalcini has published 21 popular books and continues to work at her namesake brain research institute in Italy (right).

herself to work at all levels to improve the state of Italian science. A socialist by lifelong conviction, she became good friends with Prodi, who had been prime minister in two centre-left governments. After she was made senator for life in 2001, she showed up for every parliamentary vote to support Prodi's fragile coalitions.

She also champions social issues related to research, such as ethics and women in science. The Rita Levi Montalcini Foundation has supported education for more than 6,000 African women - "to improve their chances of becoming scientists", she says. A keen writer, she has published 21 popular books. As a young bookworm, her favourite among the classics was Emily Brontë's tale of dark passion, Wuthering Heights. Such romantic inclinations remained literary though - despite a brief engagement while at medical school, she never had any long-term romances. In a 1988 interview with Omni magazine she said, tellingly, that even in a marriage of two brilliant people, "one might resent the other being more successful".

One of her remaining desires has been to leave as a legacy a well-run research institute of international significance in her country, where underfunding, inefficiency and bureaucracy have crippled much of the state research system. The Santa Lucia Institute in Rome, keen to expand its own research activities, offered rent-free premises for the first ten years of her neuroscience institute. But the EBRI is now looking shaky. Levi-Montalcini expected the government to make funds available for running the institute, but in the event the Prodi government provided only a one-off donation of $€ 3$ million (US\$4 million) just before its demise one year ago - and no other major donor was found. The right-wing government of Silvio Berlusconi has shown little interest in research and the name Levi-Montalcini cuts no ice with it.

The EBRI, which now has a staff of 28, runs with an annual deficit of $€ 200,000$. Earlier this year, University of Turin neuroscientist Piergiorgio Strata took over as scientific director with a mandate to turn things around. "We need maybe $€ 3$ million per year to survive," says Strata, who is confident that he'll be successful. The ever-determined Levi-Montalcini puts her trust in him. "I'm an optimist," she says. "I still hope we can find a way to carry on."

Levi-Montalcini is now hard of hearing and sees poorly, but her mind is sharp. At the EBRI she runs a research project to see how far back NGF goes in evolution. Several young scientists are helping by trying to find out whether the factor exists in a series of invertebrates. They are gratified to be able to speak with her most days. "She is an inspiration for us," says Francesca Paoletti, one of the postdocs working there.

And they, in turn, make her happy. "I am not afraid of death - I am privileged to have been able to work for so long," says Levi-Montalcini. "If I die tomorrow or in a year, it is the same - it is the message you leave behind you that counts, and the young scientists who carry on your work." And with that, clutching her micrographs of NGF in octopus tissue, she walks away on the arm of a friend, with a slow but stately gait. With her high heels and the swing of her tailored coat, she still looks as though she stepped off the pages of a fashion magazine. Alison Abbott is Nature's senior European correspondent.

1. Hamburger, V. J. Exper. Zool. 68, 449-494 (1934).

2. Levi-Montalcini, R. \& Levi, G. Arch. Biol. Liège 54, 189-200 (1943).

3. Levi-Montalcini, R. Ann. N. Y. Acad. Sci. 55, 330-343 (1952)

4. Cohen, S. J. Biol. Chem. 237, 1555-1562 (1962).

5. Levi-Montalcini, R. \& Booker, B. Proc. Natl Acad. Sci. USA 46, 384-391 (1960).

6. Angeletti, R. H. \& Bradshaw, R. A. Proc. Natl Acad. Sci. USA 68, 2417-2420 (1971).

7. Levi-Montalcini, R. et al. Progr. Neuroendocrinol. 3, 1-10 (1990). 